\title{
What's the problem, Mr. Smith? Shedding more light (than Heat) on Adam Smith's view of man *
}

\author{
Emmanoel de Oliveira Boff ${ }^{* *}$
}

\begin{abstract}
Why has the "Adam Smith Problem" recently been discussed in the literature? Although most historians of economic thought regard the problem solved, these discussions cast doubt on this apparent solution. This article suggests that the "Adam Smith Problem" may originate from the concept of the human being developed by Smith in the "Theory of Moral Sentiments": in this book, human beings can be understood as composed of an empirical and a (quasi) transcendental side, in the form of the impartial spectator. It is argued that it is the tension between these two parts which creates supposed inconsistencies between aspects of the "Theory of Moral Sentiments" and the "Wealth of Nations" like, for example, the role of sympathy and self-interest in each of these books.
\end{abstract}

Keywords: Adam Smith; “Adam Smith Problem”; Concept of human being; James Otteson; Vivienne Brown.

\section{Resumo}

Qual é o problema, Sr. Smith? Deixando a visão do homem de Adam Smith mais clara (e menos inflamada) Qual a razão das recentes discussões sobre o "Adam Smith Problem” na literatura? Embora a maioria dos historiadores do pensamento econômico considere o problema resolvido, estas discussões põem em dúvida esta suposta resolução. Este artigo sugere que o "Adam Smith Problem" pode ter como origem o conceito de ser humano desenvolvido por Smith na "Teoria dos Sentimentos Morais": neste livro, os seres humanos podem ser compreendidos como compostos de uma parte empírica e outra (quase) transcendental, na figura do espectador imparcial. Argumenta-se no artigo que é a tensão entre estas duas partes do ser humano que gera supostas inconsistências entre determinados aspectos da "Teoria dos Sentimentos Morais" e da "Riqueza das Nações", como, por exemplo, o papel da simpatia e do auto-interesse em cada um destes livros.

Palavras-chave: Adam Smith; “Adam Smith Problem”; Conceito de ser humano; James Otteson; Vivienne Brown.

JEL B12, B31.

\section{Introduction}

Since the publication of Raphael and McFie's1982 [1976] Introduction to the Theory of Moral Sentiments, the old "Adam Smith Problem" has mostly been considered a "pseudo-problem based on ignorance and misunderstanding"1.

${ }^{*}$ Article received on October 29, 2015 and approved on May 7, 2017.

** Associate professor at Universidade Federal Fluminense (UFF), Niteroi, RJ, Brasil. Email: emmanoelb@gmail.com.

(1) See also Raphael (2007, p. 119). 
However, recent Smith scholars insist on an ongoing discussion about the "Problem"2. This shows that, despite a debate that spans more than 160 years, there remains an inconsistency in Adam Smith's thought regarding the psychology of human action and the relation between ethics and economics. Is this tension still worth looking into or is the discussion of the "Problem" something like "flogging a dead horse"?

This paper argues that the "Problem" is still in need of clarification - despite all the heat which the discussions about it have generated in the last decades. This need for more light comes from the fact that the solutions proposed so far have not abolished the "Problem" once and for all - and this is a historical fact that needs explanation. The central line of the argument developed herein is that the apparent different views of humans in Smith's two books - the "Theory of Moral Sentiments" (henceforth TMS) and "The Wealth of Nations" (henceforth WN) - stem from a dual and circular view of human nature existing in Smith's works. This dual view is not equivalent to the traditional division between the "sympathetic nature" of humans in the TMS versus the "self-interested nature" of humans in the WN. This initial form of the "Problem", roughly deployed by German economic thinkers in the $19^{\text {th }}$ century, seems to have been abandoned since, at least, MacFie and Raphael's contribution.

What will be argued is that this apparent traditional division between sympathy and self-interest rests on a more fundamental and tensional view of humans: on the one hand, it involves the depiction of humans as (quasitranscendental Kantian) subjects capable of generating moral knowledge about one another's actions. On the other hand, humans are simultaneously depicted as empirical beings acting morally on the basis of passions and the capacities of imagination and sympathy ${ }^{3}$. It is the indeterminacy between the quasitranscendental side and the empirical side of human beings which generate many types of "Adam Smith Problems".

If this fundamental view turns out to be convincing, it may be possible to unify the recent partial explanations regarding Smith's "Problem" within a single framework. This does not mean that the "Problem" will have been solved once and for all. What it does mean is that it may be possible to give an underlying explanation for the different and partial solutions to the "Problem".

(2) In order to be brief, when we say the "Problem" we are referring to the "Adam Smith Problem". Among the most significant contributions regarding the "Problem" are Otteson (2002), Montes (2004), Brown (1994, 2009).

(3) For readers that are familiar with the work of Michel Foucault, this reading of Smith's view of human beings can strike a chord with the figure of "Man" in "The Order of Things" (1966). This is not a coincidence. Though Foucault does not analyze the TMS in "The Order of Things", it is quite plausible to assume that, because Smith found himself in the modern episteme, his conception of humans is similar to that of many scholars which, at the beginning of the 19th century, helped form the field of knowledge which Foucault termed the "human sciences". 
The article is thus structured into five sections (including this introduction and the concluding remarks). Section 2 presents a brief summary of the "Problem" and the "classical" solution advocated by Raphael and McFie (1982 [1976]), along with the frailties of their solution. Section 3 describes Raphael and MacFie's contributions to the solution of the "Problem" and presents the answers proposed recently by James Otteson (2002) and Vivienne Brown (1994, 2009). Finally, section 4 presents evidence that Smith sees humans both as quasi-transcendental Kantian subjects of (moral) knowledge and as empirical beings moved by passions and capable of imagination and sympathy. It will be shown that this underlying view of humans is coherent with Smith's account of human beings, and that his account opens windows to different "Problems" of Adam Smith (together with possible and partial solutions to it). Section 5 concludes the paper.

\section{Historical background of the "Problem" and Raphael and MacFie's solution}

\subsection{A (very) brief history of the "Adam Smith Problem"}

What is the "Adam Smith Problem"? Why did it arise and why has it not yet been completely solved? Because the "Problem" changed historically, it is necessary to present a short summary which explains why the problem appeared in the first place, how it changed over time, and why it has not been unequivocally solved ${ }^{4}$.

In its first form, the "Adam Smith Problem" first appeared in Germany in the 1840's and 1850's. It arose in the context of a discussion of the WN by two members of the Older German Historical School - Bruno Hildebrand and Karl Knies. Hildebrand criticized the WN because it was supposedly based on an atomistic and egotistical conception of human psychology. Knies observed that Smith's two books contain different conceptions of human psychology: while the TMS emphasized sympathetic feelings, the WN placed an exclusive emphasis on self-interest to explain the economic behavior of agents. The reason for this shift in Smith's ideas between the publication of the TMS (first edition in 1759) and the WN (first edition in 1776) would allegedly lie in his encounter with the French economists in 1766. Here is the root of the "Problem" in its first guise: Smith would have undergone a change of mind while in France, and that would make it difficult to understand the TMS and the WN as parts of a unique moral philosophical project.

When Witold von Skarżyński published a highly critical book in 1878 on Smith as a moral philosopher and an economist, Smith's writings seemed to be

(4) For a thorough and recent study on the history of the "Problem", see Montes (2004). He identifies three phases of the debate: the first phase centered on Germany, at the end of the 19th century. The second phase came with the publication of the complete Glasgow Edition of Smith's works, in 1976. After the publication, the "Problem" seemed solved. And finally, the third phase of the "Problem" started in the 1990's, during which time new discussions about the "Problem" arose. 
considered by German-speaking economic thinkers as inconsistent. In Skarżyński's view, the TMS was a book of an "idealist" philosopher, with one of its basic concepts being that of an ideal impartial spectator who would judge the actions of others. Meanwhile, his stay in France made him the practical, materialist political economist of the WN. The reason for this inconsistency is the fact that, while sympathy seemed to work as the main motive for action in the TMS, self-interest would play the leading role in the WN. So, the "Problem" to be solved is how to recognize consistency between the TMS and the WN - to explain how they could have been written "by the same man" - given that they give different descriptions of human motivation. In Skarżyński's opinion, Smith had "divergent and irreconcilable views of human conduct" (Montes, 2004, p. 32).

A few years later, the publication in 1896 by Edwin Cannan, of a student report of Smith's 1763-1764 Lectures on Jurisprudence (henceforth LJ) struck a blow against the idea that there would be two different conceptions of human psychology in the works carried out by Adam Smith. The report made it clear that the LJ worked as a bridge between the TMS and the WN: they are peppered with references to both the theory laid out in the TMS (like the presence of sympathy, passions and the spectator) and the examination of "political regulations" which could increase the "power and prosperity" of a country. Those issues were the object of part of his studies in jurisprudence, and would later make up the material which would become the WN.

The publication of the Glasgow Edition of Smith's Works, in 1976, finally provided scholars with a reliable source in the hope of finally clarifying the "Problem". In the "Introduction" of the TMS, MacFie and Raphael, the Editors of the Glasgow Edition of Smith's works, considered the "Problem" non-existent and based on a continuous distorted or incomplete reading of Smith. Their attack is based on two fronts: first, on textual evidence present in Smith's oeuvre; and second, on the idea that sympathy could be equated to a motive for action, like benevolence, compassion or pity. A brief elaboration of this will be given as follows.

As regards to the first point, Raphael and MacFie remark that in the Advertisement for the $6^{\text {th }}$ Edition of the TMS (published in 1790), Smith promises a book on law and government, a task which he said he had "partly executed". That is, following Smith's own writings and presumed intentions, it seems that the WN was a natural sequence for the TMS. And, as previously pointed out, the publication of the reports of Smith's LJ made it clear that there was a link between Smith's moral philosophy and his thoughts on jurisprudence. That is, the reports showed that his theory of moral approbation based on sympathy and the feelings of spectators and his investigation of systems of justice and "police" went hand in hand. The connection to political economy is developed in the "police" part of the Lectures. "Police" here means the regulations of the "inferior parts of the government, viz., 
cleanliness, security and cheapness or plenty" (V: 490). As a supposed final nail in the "Problem's" coffin, the LJ also contain a Draft of the WN, showing how, in the period between 1762-1764 Smith was already developing his views on his economic opus.

As for the second point, MacFie and Raphael also point out that the "Problem" vanishes once one considers that sympathy is not a motive for action for Smith, as Skarżyński and other members of the German Historical School seemed to imply. Sympathy is central to understanding the formation of one's moral judgment, but it cannot account for a person's actions, according to the first chapters of the TMS. Because the original "Problem" revolved around the notion of different motives for action present in the TMS (sympathy) and WN (self-interest), this observation by MacFie and Raphael, if correct, effectively dissolves the problem.

However, instead of remaining buried once and for all, the "Problem" kept reappearing during the $20^{\text {th }}$ century. Two important articles by Jacob Viner (1927, 1968) compare the TMS and WN and point to substantial differences between them. In the 1927 article, Viner says that the TMS is the work of an idealistic and young Smith as a moral philosopher, whereas the WN would be the mature, realist work of an economist. The inconsistency here lies in the idealist versus realist approaches used by Smith in the different books.

In the 1968 entry for the International Encyclopedia of Social Science, Viner put forth the proposition that Smith developed partial and different models in the TMS and the WN. Although this move eliminates any inconsistency between the two books, the tension between the TMS and the WN remains untouched. That is, the relation between the two books as part of a unique moral-philosophical project remains elusive, since they seem to occupy different domains of investigation.

From Viner's contribution onwards, it seemed for a moment that the problem was effectively solved. During the 1970's and 1980's, books by T. D. Campbell (1971), Donald Winch (1978) and Knud Haakonsen (1989 [1981]) seemed to immediately dismiss the "Problem". But, perhaps contrary to MacFie and Raphael's hopes, the "Problem" continued to be discussed by historians of economic thought during this same period. Articles by Anspach (1972), Teichgraeber (1981) and Dickey (1986) attest to this ongoing discussion and question the extent to which the TMS can contribute to Smith's economics in the WN or if the "Problem" was effectively solved. The 1990's and 2000's saw an upsurge of interest regarding the "Problem", starting a third phase of debates from a series of different perspectives. This is where we stand at present.

So far, it seems that the solution to the "Problem" proposed by MacFie and Raphael did not placate the interest of scholars regarding the proper relation between 
the TMS and the WN. That is, considering Smith's writings and presumed intentions along with the role of sympathy as a constituent of moral judgment (and not as a motive for action), it has not been enough to do away with the "Problem". Had it in fact been dissolved after the publication of the definitive Glasgow Edition of Smith's Works, there would have been fewer and fewer discussions about it. This is not what happened. Hence, it seems that there may be weaknesses in Raphael and MacFie's account of the solution to the "Problem".

\subsection{Possible weaknesses in MacFie and Raphael's account of the "Adam Smith Problem"}

The first possible weakness regards the identification of an explicit connection between the TMS and the WN. It is clear that the findings of two students' reports of Smith's LJ clarify the relation between Smith's moral philosophy and his jurisprudence. But, even so, two problems linger: first, one cannot conflate Smith's notion of jurisprudence with what he understood to be political economy in book IV of the WN. That is, creating a link between the TMS and jurisprudence is not the same as creating a link between the TMS and Smith's political economy. Jurisprudence comprised both justice issues (considered of utmost importance to Smith) and "police" issues. As previously observed, "police" involved governmental regulations of activities as diverse as those involving "cleanliness, security and cheapness or plenty". It is only the "cheapness or plenty" part that involves the production, distribution and consumption of goods and services.

The second problem is that, surprisingly, when Smith published the WN he made no explicit connection to the TMS: not once does he mention impartial spectators or sympathy in the WN in the same technical sense as he did in his first book. To say that this is due to the fact that the scope of the $\mathrm{WN}$ is narrower than that of the TMS will not do: Otteson (2002, p. 163) remarks that the WN deals with production, commerce, education, religion, history, government, different systems of political economy and so forth. So, it is not a narrow perspective at all. This lack of an explicit connection opens up the possibility for investigations regarding the relation between the two books - which is exactly what the "Problem" is about. In sum, MacFie and Raphael's tactic of resorting to Smith's writings and presumed intentions to make sense of the relation between his two books seems not to solve the "Problem" with certainty. There is not an empirical, crystal clear connection between the TMS and WN in Smith's writings. The evidence regarding this connection exists, but the nature of this connection - whether it is problematic or not - remains uncertain.

Another possible weakness regards the role of sympathy in Smith's thought. As Montes (2004, p. 45 and ff.) elucidates, it is not clear that sympathy cannot be a 
motive for action. In fact, as Raphael recently admitted (2010, p. 116), Smith himself presents two passages in the TMS where sympathy works as a motive. So, Raphael says that "Smith himself bears some responsibility for the misunderstanding that formed the Adam Smith problem" (2010, p. 116). The concrete fact is that, in practice, the imaginative projection of other people's feelings - the capacity to sympathize - can effectively work as a motive for action ${ }^{5}$. This happens, for example, when we feel the urge to help someone afflicted with poverty or disease by giving them money or sympathizing with their situation. So, when right at the beginning of the TMS, Smith writes that "sympathy (...) may now (...) be made use of to denote our fellow-feeling with any passion whatsoever" (TMS, p. 61 ), he is not excluding the feelings of compassion or pity from sympathy. In other words, sympathy denotes a fellow-feeling - and, as such, it can propel us into action.

If sympathy can in fact be a motive for action - be it in the form of a feeling of benevolence, compassion or pity - the solution to the "Problem" proposed by Raphael and MacFie cannot be considered final. This happens because the association of sympathy with the understanding of a situation by a spectator (and not with benevolence, as Khalil, 2006, p. 6, shows) was an integral part of their solution. It was precisely the association of sympathy with benevolence in the TMS which characterized the initial German version of the "Problem".

Keeping this in mind, we hope to have shown that MacFie and Raphael's solution to the problem is open to attack both in terms of their analysis of the concept of sympathy and their use of Smith's writings and presumed intentions. Neither one is a guarantor of a lasting solution to the "Problem". This justifies the quest for new forms to deal with it.

\section{Otteson (2002) and Brown (1994): new tentative solutions to the "Adam Smith Problem"6}

\subsection{The contributions of MacFie and Raphael}

So, what is left of the discussion? Despite not yielding a final solution to the "Problem", MacFie and Raphael provided useful clarifications on it. Based on their contributions, it is fair to assert that the "Problem", in its initial form, is no longer plausible.

(5) Ashraf et. al., for example, go as far as to claim that "[Smith] viewed [sympathy] as one of the most important passions" (2007, p. 92). While this assessment of sympathy as the "most important passion" may be too strong (since in the first book of the TMS, Smith points to the fact that sympathy is primarily a capacity to put oneself in another's shoes), this reading is nonetheless possible, since, as we showed, sympathy can work as a motive for action.

(6) In Annex 1 we add a schematic view of the core structure of the TMS so as to facilitate the understanding of the connection between sympathy, imagination, the impartial spectator, virtues, and judgments of actions in the book. 
The first clarification concerns the possible compatibility between Smith's view of man on the TMS and WN. More specifically, the "prudent man" of the TMS - in the "steadiness of his industry and frugality, in his steadily sacrificing the ease and enjoyment of the present moment" is certainly "supported and rewarded by the entire of the impartial spectator" (TMS, p. 227) ${ }^{7}$. When we compare this picture with the WN's "frugal man", prompted by the calm, dispassionate and constant desire to better his own condition, there is no reason to suppose that the impartial spectator would not approve of him, too. So, there seems to be no incompatibility between the prudent and the frugal man. This observation alone, however, is hardly sufficient to decree an end to the "Problem". It is still not clear why sympathy and the impartial spectator did not need to appear at all in the WN. One could ask, for example, under what definition and under which conditions Smith's self-love could single-handedly (that is, without any reference to sympathy or the impartial spectator) lead to the creation of wealth and prosperity of a nation. A question like this makes it clear that the specific connection between the two books cannot be said to be unequivocal - and so, the "Problem" persists, even if now in a different form.

The second clarification given by MacFie and Raphael concerns the status of sympathy in Smith's TMS. Despite not being confined to the human capacity of imaginatively projecting the agent into other people's situations, they made it clear that sympathy as a capacity for understanding cannot be joined together with a motive for action. The former is a condition for moral judgment, whereas the latter can be used to explain or describe an action. These are different things. As Charles Griswold Jr. (2006, p. 25) explains, there is a difference between sympathy in a narrow sense (as an emotion) and in a broader, Smithian sense (as a condition of possibility of moral judgment). As we will see in the fourth section, the conflation of conditions of possibility for moral actions and empirical motives to action is one reason why Smith's view of man clarifies many possible “Adam Smith's problems”.

Two recent attempts to solve the "Problem" were made by Vivienne Brown and James Otteson. Why are we using precisely these two scholars ${ }^{8}$ ? Because they deal with the weaknesses of MacFie and Raphael's account of the "Problem": Brown criticizes the way one makes use of Smith's writings and presumed intentions in order to understand him, while Otteson extends the use of sympathy to commercial societies in what he calls the "principle of familiarity".

However, Brown and Otteson disagree as to the present status of the "Problem". Brown admits that she attempts to solve one aspect of the "Problem", and that there are nowadays many ways to pose the "Problem". Otteson is more ambitious, writing that his proposed solution can "at the long last, lay the Adam

(7) This notation refers to page 227 of the Edition of the TMS mentioned in the Bibliography.

(8) There are many more recent contributors to the "Problem" that we have no space to rehearse here. For a list of recent contributions, see Brown (2009). 
Smith Problem to rest" (2002, p. 198). I will disagree in a qualified way with Otteson's assessment: it is not true that his solution clearly abolishes the "Problem". In fact, Otteson himself (2002, p. 193) admits that "trouble remains" when attempting to accommodate certain parts of the WN into the framework of the TMS, like the role of ambition in both books. This means that even if one accepts just one picture of man in both the TMS and the WN like MacFie and Raphael suggest and Otteson accepts - there is still room in our analyses to question the relation between both books.

\subsection{Vivienne Brown's literary contribution to the "Adam Smith Problem"}

Brown's proposal involves an interesting inversion in order to solve the "Problem". Based on the work of Russian linguist Mikhail Bakhtin, she suggests that we should study texts that do not focus on trying to discover what the author really meant to say. From her point of view, it is not interesting to show that the TMS and the WN were "written by the same man", as MacFie and Raphael try to do. The reason for her suggestion stems from the fact that the criterion of authorship is not as obvious as it appears. That is, the fact that somebody intentionally wrote a text is not sufficient to give it a final, true meaning attached to the author's intentions. But why not?

\subsubsection{The importance in studying texts as social products}

Texts are no doubt produced by individual persons, but their production is eminently social - that is, it involves the related and regulated activities of a group of writers. We can easily verify this by looking at the bibliography section of any academic article: it is the practical and interrelated work of many different researchers put together by one person's hands and head that makes up a text. A text, therefore, must not be seen as the invention of an isolated individual conscience transmitting a precise meaning to a piece of paper by means of words or other signs.

No doubt authors have intentions, are conscious, and want to communicate a meaning to their writings. But, from a social point of view, individual authors cannot control how other people will read their texts and relate them to other texts. In virtue of the social character of texts, it is always difficult to find their ultimate meaning: it always depends, to a large degree, on the changing social rules of reproduction, circulation and reading of texts. It is quite different reading the WN during the French Revolution and reading it during the conservative political and economic turn in the late 1970's in the USA and the UK. In this example, the meaning of the WN changes as the context changes. 


\subsubsection{The application in the TMS: dialogism}

Due to all of these difficulties involving the discovery of what Smith "really meant", Brown recommends that we find a way of reading his texts so as to make the TMS and the WN compatible. As she points out in the second chapter of her 1994 book, we should try to find which "voices" speak in each book. "Voices" can be understood here as the different social speech types that are allowed to enter each kind of discourse.

For Brown, the discourse of the TMS would be dialogical, that is, it would be "characterized by multivocity and heterodoxy" (1994, p. 31), like the discourse of a novel. Brown presents evidence that, besides speaking as an author who wants to transmit information about the formation of moral judgments, Smith also "invites" the reader to participate in the evaluation of actions to be judged by the "character" of the impartial spectator. In other words, one can find at least three different voices in the TMS: that of Smith himself (the authoritative voice), that of the reader who is invited to take part in the construction of moral judgments (the voice of the common person, or the voice of humanity) and finally, that of the impartial spectator (who is the final arbiter of the approval of the action).

\subsubsection{The application in the WN: monologism}

The discourse of the $\mathrm{WN}$ is different in that it is monologic, which is the typical discourse of science. In this type of discourse there is just one didactic voice. It presupposes that the author is the only cognitive subject allowed to speak, and that he or she must explain how a specific part of the objective world functions. In this case, the presence of other voices in the text only add to the author's voice - be it in examples that make the author's point clearer and better founded, or in examples that $\mathrm{s} /$ he must refuse in order to defend his or her position.

\subsubsection{Assessment of Brown's contribution}

It is due to this difference that the "Problem" appears. But it is solved, according to Brown, if we pay attention to the fact that we are dealing with two different discourses that demand different rules to be read, to circulate and to be reproduced. The presence of an authoritative author in the $\mathrm{WN}$ is replaced by the play between author, reader and impartial spectator in the TMS. Within a dialogic, moral discourse, the moral agent is capable of making moral judgments by means of the impartial spectator and the capacity to sympathize with others. This is not necessary so in the WN: within a monologic, economic discourse, there is no need for a multiplicity of voices to show how agents pass judgments. The authoritative professor explains how self-interested behavior of economic agents, constrained by a positive system of law, can increase the wealth of nations and their people. 


\subsection{James Otteson and the "principle of familiarity" as a contribution to the solution to the "Problem"}

Otteson solution to the "Problem" involves two parts: in the first part, he argues that "a single conceptual model for understanding the growth and maintenance of human institutions underlies both [the TMS and the WN]" $(2002$, p. 171). This is the market model. The second part involves an extension of the concept of sympathy to the WN through the "principle of familiarity", which would also underlie both books. If Otteson is right, it is these two characteristics that tie together Smith's books, thus solving the "Problem".

\subsubsection{The market model}

Otteson interprets the development of moral standards as an "unintended result of the numberless free exchanges people make with one another of their judgments of one another's motives and actions" (2002, p. 172). A "marketplace of morals", in this case, denotes an abstract place where the regular exchange of moral judgments by an indefinite number of people spontaneously gives rise to an ordered system. According to Otteson's interpretation of Smith, it is the constant exchange of moral judgments (based on sentiments of approbation and disapprobation) that slowly inculcates habits and routines in people's behavior. As time passes, these habitual behaviors (and the related moral sentiments of approbation) become rules or protocols for action. This process slowly allows long-term associations between people and results in common standards of morality shared by a group.

Can something similar happen in the economy? Otteson believes so: if it is true that the constant "desire to better one's condition" is approved by the impartial spectator, then self-interested behavior can become habitual. In order to reap the fruits of their own efforts, people will need a system of norms to guarantee that no one trespasses any property or free-rides on the efforts of another. So, these norms can become codified as laws in institutions (like the judicial branch of a government). Finally, these laws guarantee the maintenance of a system of private property and voluntary contracts that enforce the application of punishments and rewards. This is how, starting from a "marketplace of morals", one can evolve to a proper economic marketplace. Based on the same common model, one can say that there is a link between the TMS and the WN: the former explains how institutions regarding norms of general behavior unintentionally arise, whereas the latter clarifies how market and judicial institutions unintentionally arise from selfinterested behavior.

\subsubsection{The "familiarity principle"}

Put simply, the familiarity principle states that "people's natural benevolence towards others varies directly with their familiarity with them" (2002, 
p. 171). This means that it is easier for me to sympathize with the feelings of somebody who belongs to the group I am usually involved in when I make transactions. That is, the closer I am acquainted to someone, the more benevolent I will tend to be to this person. With the "marketplace of morals" proposed by Otteson, it is not difficult to see why members of a certain group, in their exchanges, develop a specific series of habits (and an assortment of moral sentiments associated with them). When the impartial spectator sees a strong negative deviation of behavior in this group, s/he will not hesitate to condemn the warped actions of such a person: his or her feelings of disapproval will tend to drive him or her to do so. However, how could the impartial spectator sympathize with the actions of members of a totally different group? Such sympathy is not likely to be felt, since the impartial spectator may not comprehend the social character of the situation in which the person of a very different group is part of. Without sympathy, the sharing of feelings is compromised. So, one cannot expect benevolent behavior from a stranger to the same extent that one expects it from a relative or friend.

What takes place, however, is that the new "commercial societies" of Smith's time were characterized by the growth of cities, the enclosure of lands and the industrial revolution. These social phenomena uprooted people from their familiar environments and threw them into big cities where strangers were the rule. So, if we apply this rationale to the $\mathrm{WN}$, we can see that relationships with strangers are the norm in extended market economies. Owing to the familiarity principle, it would be unwise to expect a benevolent behavior from butchers, bakers or brewers in big cities. In an extended market situation, the safest desire one can trust another to have is self-love and the desire to better one's condition. For this reason, as Smith says at the beginning of the WN, only "a beggar chooses to depend chiefly upon the benevolence of his fellow citizens" (WN, p. 73) 9

\subsubsection{Assessment of Otteson's contributions}

With this explanation, Otteson believes to have found a solid connection between the TMS and the WN, solving definitively the "Adam Smith Problem". The reason why the cardinal virtues and the impartial spectator are not mentioned in the WN is that, in extended "commercial societies", self-love is the best guide for the impartial spectator to comprehend and judge other people's behaviors. But is his solution definitive?

Otteson himself admits that it is difficult, for example, to square the role of self-interest as ambition in the TMS with self-interest as desire to better one's condition in the WN. It is true that an impartial spectator would correctly approve

(9) Of course, this does not exclude the possibility that one develops, over time, an amicable relationship with his or her commercial partners. This is however not the rule in an extended market. 
of one's desire to have a better life. However, this same impartial spectator could also self-deceptively approve of an ambitious person only seeking the "pleasures of wealth and greatness" (2002, p. 195). In fact, in two long paragraphs in the TMS, Smith describes the saga of an ambitious "poor man's son" (TMS, p. 200) who rises from rags to riches, only to discover at the end of his life that "power and riches appear then to be, what they are, enormous and operose machines contrived to produce a few trifling conveniences to the body" (TMS, p. 202). But even if power and riches can deceive the judgment of a spectator, they can maintain "the continual motion [of] the industry of mankind" (TMS, p. 202).

What about the role of self-interest as ambition in the WN? In a recent contribution to the "Problem", Paganelli (2008) shows that it is not in the WN, but in the TMS, that self-interest in the form of ambition can be useful to bring about the progress of nations. In her words, in the WN, "individual self-interest, when backed by the power of government, is left unbound to enrich a few at the expense of many" (2008, p. 380). That was exactly the criticism Smith leveled against mercantilist doctrines in most of Book IV of the WN. In other words, self-interest understood as ambition is bad for the wealth of nations. We are left, then, with a new and inverted form of Smith's "Problem": self-interest as ambition is good in the TMS and bad in the WN. As a consequence, the "Problem" remains when one discusses the role of ambition in Smith's two books.

This criticism is not meant to dismiss Otteson's solution to the "Problem", but to show that, in his own admission, it has limitations. Even though the "Problem" in its German form is no longer defensible, doubts remain regarding the psychology of human action in the TMS and WN. The evidence we presented so far points to the need to investigate with more depth what might lie behind this specific aspect of the "Problem". Brown (2009) seems to be right on point when she says that it is necessary to investigate the notion of agency (she says "the metaphysics of agency") in Smith's books in greater depth.

\section{Adam Smith's view of man: men as subjects and objects}

So far we have moved from the initial, German version of the "Problem" to the (partial) solutions by MacFie and Raphael, Brown and Otteson. In this process, the "Problem" itself changed, and the initial German contention about "sympathy in the TMS" versus "self-interest in the WN" can no longer be seriously contemplated. The contributions of the above authors highlighted the role of a different literary style of Smith's works, as well as the compatibility of Smith's view of man in both the TMS and WN.

If this is so, what can explain the persistence of the "Problem" in the literature? We will put forth the proposition that the "Problem" is caused by a dual, more fundamental and tensional view of humans: on the one hand, this view 
involves the representation of human beings as quasi-transcendental Kantian subjects capable of generating moral knowledge about one another's actions. The condition of possibility of this moral knowledge lies on the impartial spectator, this "inmate of the breast", which we create with the help of imagination and the capacity for sympathy. On the other hand, humans are depicted as empirical beings acting morally on the basis of passions and the human capacities of imagination and sympathy. The essence of our argument, therefore, is the role accorded to the impartial spectator in the judgment of our own and other people's actions.

In order to defend the hypothesis that the origin of the "Problem" lies in this tensional and double nature of humans, we will proceed in four stages: First, it will be revealed that Smith actually sees men as doubles, composed of the actual person and the imaginary, impartial spectator. It will then be shown how the impartial spectator is formed socially, and how it can influence one's actions. Thirdly, the problems and consequences of this view of man will be assessed. Finally, we will show how the different versions of the "Problem" we have studied so far - the German, MacFie and Raphael's, Brown's and Otteson's versions - can all be coherently understood within this framework.

\subsection{Evidence for the problematic dual nature of human beings in the TMS}

Having shown in the first two parts of the TMS how we judge other people's actions, Smith begins the third section of the book by showing how the impartial spectator can be used to judge our own actions. Smith clearly shows that, in this process, we must "divide ourselves into two persons", the impartial spectator and our empirical selves:

When I endeavour to examine my own conduct, when I endeavour to pass sentence upon it, and 'either to approve or condemn it, it is evident that, in all such cases, I divide myself, as it were, into two persons; and that I, the examiner and judge, represent a different character from that other I, the person whose conduct is examined into and judged of. The first is the spectator, whose sentiments with regard to my own conduct I endeavour to enter into, by placing myself in his situation, and by considering how it would appear to me, when seen from that particular point of view. The second is the agent, the person whom I properly call myself, and of whose conduct, under the character of a spectator, I was endeavouring to form some opinion. The first is the judge; the second the person judged of. But that the judge should, in every respect, be the same with the person judged of is as impossible, as that the cause should, in every respect, be the same with the effect (TMS, p. 150).

The same process happens when the spectator needs to judge the actions of a friend or a relative: it is by detaching ourselves from our own interests and prejudices in the situation that a just, unbiased judgment can be carried out. 
It is now important to see, exactly, why this division of human beings into two is problematic. In principle, the idea that humans have a dual nature is not at all new - one can go back to Plato, or Saint Augustine to find it in Western Thought. In fact, in British empiricism, of which Smith is heir, there is a strong tradition of studying people as composed of a dual nature. Particularly, in the economic realm, John B. Davis (2003, p. 5) credits Locke with giving us the "strongest possible interpretation to the Cartesian-Newtonian dualism of subject and object worlds". Locke's interpretation of individuals mentioned by Davis has two characteristics: first, Locke imagines that individuals can make their mental ideas totally free of influence like despotism and custom; that is, individuals possess an interiority that allows them to think freely. Contrary to Descartes, he did not believe in innate ideas to form the basis for knowledge, but in the association of simple ideas that come from our basic sense experience. Second, the conscience of the individual is autonomous and private. In the words of Davis (2003, p. 6),

a being understood simply as consciousness must be a private being, both because the self as pure consciousness can only be conceived in first-person terms, and because consciousness, by virtue of its intentional character, must always be separate from what conscience is of. For Locke, individuals are confined within a first-person world, with the world of real things only available to them as intentional objects.

This description of Locke's dual nature of the individual does not seem to be problematic: we have senses which are affected by an external nature, and we have impressions of these senses in our minds. These impressions are called ideas. When combined, these ideas can create knowledge. Because Locke's process of combining ideas is not tainted with social, historical and cultural circumstances, we can generate universal knowledge, independent of historical time and particular cultures. Of course, mistakes may be made in the process of combining ideas. But just as in the case of Descartes or Newton, Locke's consciousness is "separate from what conscience is of": subjects and objects are separate. Would that also be the case with Smith?

The next section will be devoted to indicating that this is not Smith's case. If the argument developed herein is convincing, then Smith's account of human nature is different from that of Locke, who rigidly separates the subjective side of people from their objective, empirical side. This will turn out to be problematic for Smith, in the sense that the judgments of the impartial spectator are always colored by the existing habits and customs of a given society. As a consequence, Smith's theory suffers from a tension between universality (which can be theoretically achieved since men are made of the same "coarse clay" and, because of that, can sympathize with any other man in the world) and cultural relativism (because the 
judgments of the impartial spectator depend on the cultural milieu where it was formed $)^{10}$.

\subsection{The social formation of conscience and the impartial spectator}

The previous quotation by Smith showed how our own passions and actions can be judged by the impartial spectator. But what exactly is the impartial spectator? Smith himself seems to equate conscience with him/her. He states, for example, that it is "reason, principle, conscience, the inhabitant of the breast, the man within, the great judge and arbiter of our conduct" (TMS, p. 166) that can correct the excesses of our self-love. A few sentences later, he says that this correction is carried out under the influence of the impartial spectator. Consequently, the impartial spectator can be understood as a conscience-like subject who has the capacity to produce moral knowledge about our concrete actions. More specifically, one can consider the impartial spectator as a quasi-transcendental Kantian subject who produces moral judgments about our objective, empirical actions. Why do we say quasitranscendental? Because the impartial spectator's origin is located in the social milieu where concrete, empirical people live. So, the spectator is not simply a purely transcendental, imaginary figure that floats above our empirical selves: its formation is impossible without the aid of society. Here is where Smith seems to depart from Locke's view of human conscience.

Smith himself supports this view. In a famous passage, he tells us that: ${ }^{11}$

Were it possible that a human creature could grow up to manhood in some solitary place, without any communication with his own species, he could no more think of his own character, of the propriety or demerit of his own sentiments and conduct, of the beauty or deformity of his own mind, than of the beauty or deformity of his own face. All these are objects which he cannot easily see, which naturally he does not look at, and with regard to which he is provided with no mirror which can present them to his view. Bring him into society, and he is immediately provided with the mirror which he wanted before. It is placed in the countenance and behaviour of those he lives with, which always mark when they enter into, and when they disapprove of his sentiments; and it is here that he first views the propriety and impropriety of his own passions, the beauty and deformity of his own mind.... This is the only looking-glass by which we can, in some measure, with the eyes of other people, scrutinize the propriety of our own conduct (TMS, p. 149, author's italics).

(10) This tension is further explored in a recent article by Fleischhacker (2011).

(11) The idea that the spectator is formed socially is supported by the vast majority of Smith's scholars. For further information in this regard see Raphael and Macfie (1982); Griswold (1999); Otteson (2002); Fleischacker (2004); Evensky (2005); Raphael (2007). 
Writing about the authority of conscience, the Scottish philosopher remarks that the impartial spectator learns to evaluate the interests of different people in an almost automatic way, by means of "experience and habit":

We must view [opposite interests], neither from our own place nor yet from [our neighbor's], neither with our own eyes nor yet with his, but from the place and with the eyes of a third person, who has no particular connexion with either, and who judges with impartiality between us. Here, too, habit and experience have taught us to do this so easily and so readily, that we are scarce sensible that we do it; and it requires, in this case too, some degree of reflection, and even of philosophy, to convince us, how little interest we should take in the greatest concerns of our neighbour (...) (TMS, p. 165, author's italics).

Thus, the impartial spectator comes to life only when we live socially. Society is the "looking glass" into which we learn which actions are proper or improper. Virtues are not in-born either, but socially learned. For example, according to Smith, the virtue of self-command can also be taught at school. Children are seen to moderate "not only their anger, but all their other passions, to the degree in which their play-mates and companions are likely to be pleased with. It thus enters into the great school of self-command" (TMS, p. 172). And education can also "correct the inequalities of our passive feelings; and we must for this purpose (...) have recourse to the severest, as well as to the profoundest philosophy" (TMS, p. 173).

Because of this, says Smith, human nature is, to a certain extent, malleable - due to social influences on the "coarse clay" of which it is made. There are many examples of this malleability in the TMS, mainly in part V of the book - "of the influence and moral and fashion upon moral sentiments". Indeed, Smith says that,

There are other principles (...) which have a considerable influence upon the moral sentiments of mankind, and are the chief causes of the many irregular and discordant opinions which prevail in different ages and nations concerning what is blameable or praise-worthy. These principles are custom and fashion, principles which extend their dominion over our judgments concerning beauty of every kind (TMS, p. 211).

Smith goes on to illustrate the enormous extent to which the judgment of beauty is influenced by habit and custom. In fact, Evensky (2005, p. 50) goes as far as to claim that, for Smith, norms of beauty "are not bounded by any natural standards, but [by] norms of behavior". That does not mean that human nature is indeterminate - the "coarse clay" from which humanity is formed is the same. However, it can be somewhat molded, even if not to perfection (TMS, p. 185). Although Smith admits that the practice of murder of new-born infants was common even in civilized societies of the past, such as Greece, he also contends that "no 
society could subsist a moment, in which the usual strain of men's conduct and behaviour was of a piece with the horrible practice I have just now mentioned" (TMS, p. 224).

Another example of the interplay between the social environment and the judgment one makes is found in chapter III of Section 3 of the TMS: it is our disposition to admire, approve of and imitate the rich - even if this is degrading. With due attention to their different contexts, Smith's analysis has similarities with Veblen's idea of conspicuous consumption and the snob-effect:

It is from our disposition to admire, and consequently to imitate, the rich and the great, that they are enabled to set, or to lead what is called the fashion. Their dress is the fashionable dress; the language of their conversation, the fashionable style; their air and deportment, the fashionable behaviour. Even their vices and follies are fashionable; and the greater part of men are proud to imitate and resemble them in the very qualities which dishonour and degrade them (TMS, p. 109).

Thus, it is even possible that people act in such a way to degrade themselves, because of this "disposition" to imitate the rich. But, of course, contra Smith, this disposition does not "consequently" lead to the act of imitating the rich, for there is always an impartial spectator that can prevent this imitation. In fact, the impartial spectator can restrain my actions, when I apply his/her judgment to myself ${ }^{12}$. For example, when Smith talks about the passions that originate in the body (that can be "furious", as in the case of sex) he deems it "indecent" to express them in "any strong degree" (TMS, p. 77). Consequently, it is possible to affirm that there is only a tendency for a passion to produce a certain behavior ${ }^{13}$. As a result, the relationship between motives for action (passions of body and imagination) and actual action cannot be said to be one of cause and effect, as in the physical sciences. If this is so, we have here an example of how the quasi-transcendental side of humans (in the form of the impartial spectator) can restrain the objective, empirical actions that would follow from our disposition to imitate the rich. The empirical and transcendental sides of human beings seem again as entwined.

In order to conclude this section, let us present the summary Haakonssen gives of this double nature of Smith's conception of human beings and the possibility of morals:

(12) It is unusual to portray the impartial spectator as having the capacity to interfere with people's actual behaviors. However, because the empirical and transcendental sides of human beings are mixed together, this is a possible interpretation of the role of the impartial spectator in concrete life. Forman-Barzilai (2011, p. 76), for example, talks about the disciplinary effects of the spectator surveillance on the agent. Raphael (2007, p. 40) comments on conscience as possessing a function of self-command.

(13) This is an important point which we cannot further elaborate here. There is ample evidence in the TMS that confirms this statement, as Brown (2009) demonstrates. 
(...) [Smith] makes his own division of the person, into the empirical self of immediate desires and actions and the ideal impartial spectator harboured in our conscience beyond the sway of desires and the necessity of action. Smith of course accounts for the formation of the impartial spectator in empirical terms as a matter of social and psychological processes. Even so, one has to allow that he is also making a conceptual point that has some similarity to Kant's transcendental argument. Given the fact of morals, how do we account for its possibility? (...) Smith's answer, in a nutshell, is the impartial spectator (...)" (Haakonssen, 1996, p. 151-152).

What Haakonssen does not show is how this dual nature of humans can generate problems between the actual actions of people and the ideal moral judgments of an impartial spectator. We will now analyze the implications of this conception of human beings present in Smith.

\subsection{Problems in the concept of the impartial spectator due to the dual nature of human beings}

We have provided many examples that point to the fact that Smith's consciousness and the impartial spectator are formed by and within the very society whose members' actual actions it judges and restrains. As we argued at the end of section 4.1, this leads to complications for Smith's moral theory. And, in fact, the first person to notice there was indeed a problem with Smith's moral theory was probably Sir Gilbert Elliot, after the publication of the first edition of the TMS in 1759. As Macfie and Raphael (1982) remark, the judgment of the impartial spectator can be no better than popular opinion, if the conscience of the individual is molded according to the institutions and habits of the society he lives in.

Smith tried to solve this problem by refining the theory of the impartial spectator. He introduces refinements in the second and sixth editions of the TMS. These refinements are meant to separate popular opinion (which is the average opinion observed empirically in the individuals of given society and epoch) from the conscience of the individual (which ideally transcends all empirical determinations so as to be able to make impartial judgments):

[Smith] says, in the revision for edition 2, that the jurisdiction of conscience 'is in a great measure derived from the authority of that very tribunal [of popular opinion], whose decisions it so often and so justly reverses'. But by the time he came to revise the work again for edition 6 , Smith had become even more sceptical of popular opinion and replaced the passage just quoted by the statement that 'the jurisdictions of those two tribunals are founded upon principles which, though in some respects resembling and akin, are, however, in reality different and distinct' (III.2.32). The judgment of the real spectator depends on the desire for actual praise, that of the imagined impartial spectator on the desire for praiseworthiness. Smith maintains the distinction in other 
parts of the new material added to edition 6, especially in his treatment of selfcommand (Macfie; Raphael, 1982, p. 26).

However, even if the desire of the impartial spectator is for praiseworthiness and not simply praise, it begs the question: what does praiseworthiness mean in different societies? It also makes us question what the final result in terms of morality is, for each different notion of praiseworthiness. In fact, the impartial spectator may be in doubt regarding the rectitude and praiseworthiness of his actions when they are unpopular in his/her own society. For example, when discussing how one should react to the "violence and loudness" of the "judgment of weak and ignorant men", Smith admits that the impartial spectator may be "shaken" regarding the rectitude of his/her actions. The reason for this vacillation is the spectator's dual nature: partly transcendental, god-like; and partly concrete, human. He poetically describes what happens in our psyche in such difficult situations:

In such cases, this demigod within the breast appears, like the demigods of the poets, though partly of immortal, yet partly too of mortal extraction. When his judgments are steadily and firmly directed by the sense of praise -worthiness and blame - worthiness, he seems to act suitably to his divine extraction: But when he suffers himself to be astonished and confounded by the judgments of ignorant and weak man, he discovers his connexion with mortality, and appears to act suitably, rather to the human, than the divine, part of his origin. (TMS, p. 162).

As a consequence, Sir Gilbert Elliot may not have been satisfied with Smith's answer to his criticism in the following editions of the TMS. After all, if the impartial spectator is torn between two different natures - one god-like and the other human - nothing guarantees that his/her final judgment is correct. As the next paragraphs will make clear, here is the source of the many sorts of "Problems" with Smith's conception of human beings.

It cannot be said, however, that Smith did not try to solve this tension in the figure of the impartial spectator. In fact, it could be interesting to analyze the new section $\mathrm{VI}^{14}$ of the TMS in light of the need to solve this tension: in this new section, Smith explains what virtues a supposedly perfectly virtuous man would have justice, benevolence, prudence and self-command. After all, why would this section be necessary, if the impartial spectator is always right, in every society? Maybe there was a danger of moral relativism which could lead to some actions - like the practice of killing new-born infants - being considered morally acceptable by a society that traditionally practiced it. As we have seen, Smith thinks that an action like that is not acceptable under any circumstance. So, it is indeed necessary to present "cardinal virtues" which are valid in all societies, so that the impartial spectator is not dependent upon the whims of this or that society. An acceptation of such

(14) Which Smith introduced in the TMS and which surfaced only a few months before his death, in 1790. 
relativism could be a menace to a theory of moral sentiments that was meant to be general, since it was based on a single, "coarse clay" conception of human nature.

After all of these examples, we are ready to state in detail what generates the "Problem" in all of the versions we have seen so far: Smith's impartial spectator is supposed to have the capacity to sympathize with any other human being in the world - and this could make his theory valid for all societies in the world. However, the spectator is formed not within any abstract "humanity", but within concrete historical cultures, which have specific values, behaviors and standards of conduct. As the above paragraph makes clear ${ }^{15}$, this generates a tension between cultural relativism and universalism in Smith's TMS. As the above quotation by MacFie and Raphael indicates, Smith spent his whole life trying to solve this problem. FormanBarzilai (2011, p. 76) suggests that one of the objectives of Smith's constant revisions of the TMS between 1759 until months before his death in 1790 was "to assert the independence of conscience" of external influences. This is important for Smith, because the independence of the impartial spectator guarantees that there are no biases in his/her moral judgment.

The fact, however, is that there is a circular contradiction between the necessary independence of the "impartial spectator" from cultural and social standards and his/her origin - hence, dependence - in these very cultural and social standards. On the one hand, the moral knowledge that the impartial spectator must produce and convey is always limited by his/her own empirical circumstances - the culture, customs and history of his/her own people. On the other hand, the empirical circumstances which give life to the impartial spectator can alter his/her judgment towards the members of his/her own community. This happens because s/he is more likely to sympathize with the feelings s/he shares with members of his/her own community, as opposed to the feelings of people of distant communities. As a result, the moral judgment so generated may not observe actual impartial, universal standards of morality.

It is the gap between the necessity of unbiased, impartial judgments and the concrete, empirical origins of the spectator that creates the many versions of the "Problem". The next section will show that the different versions of the "Problem" we have covered so far can be interpreted as attempts to fill this gap.

\subsection{The dual nature of human beings as a source for the different forms of the "Adam Smith Problem"}

Let's start with the German version of the "Problem". How did they see the gap between the quasi-transcendental side and the concrete, empirical side of humans? If one uses Skarżyński's formulation of the "Problem" as an example, it is

(15) The evidence of this tension is elaborated in more detail by Fleischacker (2011). 
possible to see that his mistake was to consider that the gap lay in the different conceptions of human nature in different books: the TMS would deal primarily with the impartial spectator as the quasi-transcendental side of humans (which Skarżyński deems an "idealist" study) whereas the WN would deal with the practical consequences for the economy of the action of self-interested individuals (it is Smith's adopted "materialism" from the French économistes, according to Skarżyński). One can also interpret Viner's 1927 article as following this same (false) mode of explanation.

As MacFie and Raphael showed, however, this explanation is obviously wrong. Textual evidence demonstrates that it was not Smith's intention to provide an "idealist" versus a "materialist" view of humans in different books. Skarżyński's account that "sympathy" would only be a motive for action in the TMS is also wrong. Yet MacFie and Raphael's were also not totally correct. As we have tried to demonstrate, the use of Smith's textual evidence and the association of sympathy with understanding are not enough to dispel the "Problem". They were correct in saying that Smith's conception of humans in his two books can be made coherent; however, this does not mean that this underlying and unique conception behind both books is not problematic in itself.

Brown and Otteson's contributions dealt differently with the gap in Smith's conception of human beings. Using insights from Bakhtin, Brown divided the individual in Smith's texts into different "voices": she treated the impartial spectator as one of the "voices" of the dialogical discourse of the TMS. Because the discourse of the WN was of a scientific, monological type, there was no need to make reference to the impartial spectator there. Brown bridges the gap that gives origin to the "Problem" by appealing to the literary practice of constructing different discourses. So, the gap we mentioned can be understood as an effect of different rules for producing and reading different texts: in a moral philosophical discourse, a plurality of voices is acceptable, and it is not necessary that each voice be unified into a coherent concept of individual. The same cannot be said of a scientific discourse. As a result, the self-interested individual is the main "character" of the WN. The "Adam Smith Problem", in Brown's 1994 version, can be tentatively understood as the problem of identifying the different voices and rules for reading and constructing distinct discourses, such as moral philosophy and political economy.

Otteson's appeal to the market model and the familiarity principle are at the core of his solution to the "Problem". His ingenious idea consisted in showing that the pervasive self-love of the WN can be approved by the impartial spectator, since in extended commercial societies self-love is the main passion one can sympathize with. This does not eliminate all other passions human beings have in other social milieus: because sympathy is stronger in small towns, families or in close 
neighborhoods, exchanges may also be backed by other sentiments, like benevolence, love or personal affinity.

What Otteson does not account for is the fact that the harmony of feelings between people in different forms of social organization is not enough to lead to and maintain a virtuous society. His own example showed how the role of ambition can be good in the case of the "poor man's son" of the TMS and bad in the case of mercantilist privileges in book IV of the WN. The reason for this apparent contradiction lies exactly in the fact that the impartial spectator is formed socially and does not have a "view from nowhere". As a result, s/he cannot know all of the consequences of his/her approval or disapproval of other people's actions. This is why the spectator can be sometimes torn between different impulses to action.

In other words: whatever the prevailing harmony of sentiments in a given society (be it commercial or otherwise), there is always a gap between the supposed impartiality of the (quasi-transcendental) spectator's judgments and the resulting empirical actions that slowly take root in concrete societies. The spectator's judgment of actions as good or bad may not square with the actual goodness or evil of empirical actions. Because the spectator has a "mortal" origin, it is possible that popular opinion veers his judgment toward the approbation of an actually bad action. In the gap between feelings-based, ideal approvals by spectators and the concrete, social consequences of these approvals, some indeterminacy as concerns the evolution of human societies appears. This indeterminacy in Smith's treatment of agents can be interpreted as the root of the permanent tension and the ongoing discussions about the "Problem".

It is this indeterminacy that does not surface in Otteson's solution. He seems to assume that the gist of the "Problem" was how to insert sympathy and the impartial spectator into the self-interested frame of the WN, so as to make TMSWN a coherent moral philosophical project. But, according to our interpretation, this is not the true gist of the "Problem". The true gist of the "Problem" lies in the aforementioned - and maybe unsolvable - basic indeterminacy in the concept of individual which Smith imparted to us.

Following the hypothesis defended herein, we can then rephrase the "Problem" - or rather, the possible "Problems" - this way: what kind of inconsistency between a given aspect of the link between the TMS and the WN can the gap between the judgments of impartial spectators and actual actions of agents lead to? And how can we try to close the gap between the judgments of supposedly impartial spectators and the consequences for society of people's actual behavior? This is, in short, our assessment of the "Problem". 


\section{Concluding remarks}

As MacFie and Raphael commented, much heat and little light has perhaps been generated by academics discussing the supposed "Adam Smith Problem". As we observed at the beginning of the paper, for MacFie and Raphael, the "Problem" is based on ignorance and misunderstanding. However, the fact that the "Problem" has continued to be discussed in the 1990's and 2000's is an unexplained historical fact which cast doubts on MacFie and Raphael's assessment. The task we devoted ourselves to in this paper is to shed more light on this historical fact.

This article showed that the dual aspect of the human nature described by Smith is problematic, and paves the way to tensions between some aspects of the TMS and the WN. We can find evidence and confirmation of this problematic nature in Smith's texts. In fact, Smith's conception of humans can be said to anticipate many of the many problems faced by the new discipline of behavioral economics ${ }^{16}$. For example, recent books by Gintis et al. (2005) and Bowles and Gintis (2011) specifically come to address the fact that the human species has evolved so as to encompass both self-interest (as in the WN) and other moral sentiments (as in the TMS). This recent understanding of human nature (which resonates well with Smith's own view) has consequences for the way microeconomists approach decision-making, since there is a constant interplay between moral sentiments and self-interest. As a consequence, when designing public policies, economists should consider as their starting point not only how self-interested agents react to a set of (usually monetary) incentives, but also how monetary incentives can crowd in (or out) our moral sentiments. A long paper by Bowles and Polania-Reyes (2012) highlights the importance of how agents "frame the decision situation so as to suggest appropriate behavior", which is clearly in line with Smith's own procedure regarding the impartial spectator.

However, none of the aforementioned authors deal with the more philosophical implications of the problematic dual nature of human beings. As we defend in this paper, this duality is a source for the old "Adam Smith Problem". The Germans were wrong to think that there are different conceptions of human agents in the TMS and WN. Though correct, MacFie and Raphael's identification of just one underlying human nature in both books is not sufficient to kill the "Problem" once and for all. Since there is a permanent gap between the ideal impartial spectator and people's actual behaviors, the "Problem" persists. Brown and Otteson's

(16) In a recent paper, Ashraf et al. (2008, p. 101) mentioned that "Adam Smith's actors in the TMS are driven by an internal struggle between the impulsive, fickle and indispensable passions, and the impartial spectator". They show how many of today's problems in behavioral economics resemble observations made by Smith regarding human nature. 
different attempts to solve the "Problem" can only be partial, since the gap is constitutive of Smith's conception of humans.

Can our assessment of the "Problem" be useful for future research? We believe so. In this paper we mentioned the tension between universalism and cultural relativism in Smith as linked to the "Problem". One could also investigate how the tension between optimism and pessimism regarding the future of commercial societies $^{17}$ can be put from our perspective of the "Problem". The role of the indeterminacy in our knowledge generated by the double nature of humans may help us see devices such as the "invisible hand" in the TMS and the WN in a different light: since our dual nature prevents us from knowing with certainty the moral results of our actions, the order we see in the social world cannot be fruit of the righteousness of humans' intentional actions. There is no way a "man of system" can order society in a determined manner. As Smith reminds us, "in the chess board of human society every single piece has a principle of motion of its own" (TMS, p. 244). We can perhaps only expect that a transcendental principle - like an invisible hand - may order what our minds are not equipped to order intentionally ${ }^{18}$.

\section{References}

ALVEY, J. Adam Smith: optimist or pessimist? A new problem concerning the teleological basis of commercial society. Hants: Ashgate Publishing, 2003.

ANSPACH, R. The implications of the theory of moral sentiments for Adam Smith's economic thought. History of Political Economy, v. 4, n. 1, p. 176-206, 1972.

ASHRAF, A. et al. Adam Smith, behavioral economist. In: LOEWENSTEIN, G. Exotic preferences. New York: Oxford University Press, 2008.

BOWLES, S.; GINTIS, H. A cooperative species: human reciprocity and its evolution. Princeton: Princeton University Press, 2011.

BOWLES, S.; POLANÍA-REYES, S. Economic incentives and social preferences: substitutes or complements? Journal of Economic Literature, v. 50, n. 2, p. 368425, 2012.

BROWN, V. Adam Smith's discourse: canonicity, commerce and conscience. London; New York: Routledge, 1994.

(17) Already studied by Alvey (2003)

(18) A similar point was made by Foucault in his 1979 course at the College de France: "The birth of biopolitics". 
BROWN, V. Agency and discourse: revisiting the Adam Smith problem. In: THE ELGAR Companion to Adam Smith. Northampton: Edgar Elgar Publishing, 2009.

CAMPBELL, T. D. Adam Smith's science of morals. New York: Routledge, 1971.

CAMPBELL, R. H.; SKINNER, A. S. (Eds.). The Glasgow edition of the works and correspondence of Adam Smith in seven volumes. Indiana: Liberty Fund, 1982 [1976].

DAVIS, J. The theory of the individual in economics: identity and value. New York: Routledge, 2003.

DICKEY, L. Historicizing the "Adam Smith problem": conceptual, historiographical, and textual issues. The Journal of Modern History, v. 58, n. 3, p. 579-609, Sept., 1986.

EVENSKY, J. Adam Smith's moral philosophy: a historical and contemporary perspective on markets, law, ethics and culture. Cambridge: Cambridge University Press, 2005.

FLEISCHACKER, S. On Adam Smith's wealth of nations: a philosophical companion. Princeton: Princeton University Press, 2004.

FLEISCHACKER, S. Adam Smith and cultural relativism. Erasmus Journal for Philosophy and Economics, v. 4, n. 2, p. 20-41, Autumn 2011,

FORMAN-BARZILAI, F. Adam Smith and the circles of sympathy: cosmopolitanism and moral theory. Cambridge: Cambridge University Press, 2011.

FOUCAULT, M. The order of things. New York; London: Routledge: 2001.

FOUCAULT, M. O nascimento da biopolítica. Curso no College de France, 19781979. São Paulo: Martins Fontes, 2008.

GINTIS, H. et al. Moral sentiments and material interests: the foundations of cooperation in economic life. Cambridge: MIT Press, 2005.

GRISWOLD, C. Adam Smith and the virtues of enlightenment. Cambridge: Cambridge University Press, 1998.

HAAKONSSEN, K. The science of a legislator: the natural jurisprudence of David Hume and Adam Smith. Cambridge: Cambridge University Press, 1989 [1981].

HAAKONSSEN, K. Natural law and moral philosophy: from Grotius to the scottish enlightenment. Cambridge: Cambridge University Press, 1996.

KHALIL, E. Smith the Hedgehog. In: BROWN, V. (Ed.) The Adam Smith review. New York: Routledge, 2006. v. 2, p. 3-21. 
MONTES, L. Das Adam Smith problem: its origins, the stages of the current debate, and one implication for our understanding of sympathy. In: MONTES, L. New perspectives on Adam Smith. New York: Palgrave, 2004.

OTTESON, J. R. Adam Smith's marketplace of life. Cambridge: Cambridge University Press, 2002.

PAGANELLI, M. P. The Adam Smith problem in reverse: self-interest in the wealth of nations and in the theory of moral sentiments. History of Political Economy, v. 40, n. 2, p. 365-82, 2008.

RAPHAEL, D. D.; McFIE, A. L. Introduction to the theory of the moral sentiments. In: CAMPBELL, R. H.; SKINNER, A. S. (Eds.). The Glasgow edition of the works and correspondence of Adam Smith in seven volumes. Indiana: Liberty Fund, 1982 [1976]. v. 1 .

RAPHAEL, D. D. The impartial spectator: Adam Smith's moral philosophy. Oxford: Oxford University Press, 2007.

TEICHGRAEBER III, R. Rethinking das Adam Smith problem. Journal of British Studies, v. 20, n. 2, p. 106-123, Spring 1981.

VINER, J. Adam Smith and laissez faire. Journal of Political Economy, v. 35, n. 2, p. 198-232, Apr. 1927.

VINER, J. Adam Smith. In: SILLS, David L. (Ed.) International Encyclopedia of the Social Sciences, 1968. v. 14, p. 322-329.

WINCH, D. Adam Smith's politics: an essay in historiographic revision. New York: Cambridge University Press, 2008 [1978]. 


\section{Annex 1}

\section{Core structure of Smith's TMS}

Motives or reasons for human action

(stemming from passions of the body and imagination)

Explains virtues:

Justice, benevolence, prudence, self-command

Explains self-love

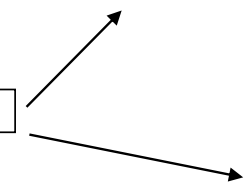

(By means of the desire of social approval)

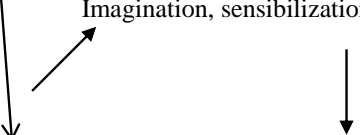

Impartial Spectator

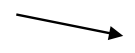

Moral Judgment of action

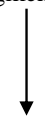

Conscious approval of the action

Just

Virtuous actions are:

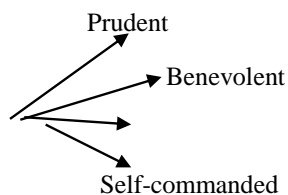

